\title{
HUBUNGAN ALIH FUNGSI LAHAN DAN PERUBAHAN IKLIM TERHADAP HASIL KOMODITAS PERTANIAN DI JUMANTONO
}

\section{Ayu Prilyscia', Sutarno², Rahayu²}

1) Alumni S1 Program Studi Agroteknologi, Fakultas Pertanian, Universitas Sebelas Maret Surakarta

2) Dosen Program Studi Agroteknologi, Fakultas Pertanian, Universitas Sebelas Maret Surakarta

Author Contact: prilyscia94@gmail.com

\begin{abstract}
Land use conversion is a phenomenon of land use changes. The changes of land use and climate will affect on agricultural productivity. The purpose of this study was to analyze the changes of land use and climate that occurred in Jumantono District and the correlation between the land use conversion and the climate changes to agricultural productivity. This research was conducted in Jumantono District and Laboratory of Pedoogy and Climatology in Agriculture Faculty. Data be analyzed quantitavie descriptively and by correlation. The results showed that there was a change of land use area according to BPS in 2006-2007 and according to Google Earth Image analysis in 2004-2011 or 2011-2014 there ware changes of land use. Statistical analysis showed that land use changes and climate changes was significally correlated with land productivity.
\end{abstract}

Keywords: Land Conversion, Climate Parameter, Land Prooductivity

AGROTECHNOLOGY RESEARCH JOURNAL

Prilyscia A, Sutarno, Rahayu. 2018. The correlation of land conversion and climate changing to agricultura producticity in jumantono. Agrotech Res J 2(1):28-34.

Prilyscia A, Sutarno, Rahayu. 2018. Hubungan Alih Fungsi Lahan dan Perubahan Iklim terhadap Hasil Komoditas Pertanian di Jumantono. Agrotek Res J 2(1) :28-34.

\section{PENDAHULUAN}

Kecamatan Jumantono merupakan salah satu kecamatan yang ada di Kabupaten Karanganyar memiliki luas wilayah 5.354 Ha. BPS Kabupaten Karanganyar (2009) dalam (Priyono, 2011) menuliskan bahwa selama tahun 2006 sampai tahun 2009 telah terjadi pengurangan lahan sawah seluas $366,43 \mathrm{Ha}$ atau sekitar $1.6 \%$ areal sawah berkurang sejak tahun 2006 hingga tahun 2009. Pengurangan areal persawahan ini telah dialokasikan untuk perumahan, industri, jalan dan lain-lain sebagai penunjang aksesibilitas penduduk.

Pengalihfungsian lahan akan berakibat terhadap perubahan hasil produktivitas lahan tersebut. Penurunan produktivitas lahan pertanian yang diakibatkan oleh alih fungsi lahan dapat bersifat permanen dan sulit untuk diperbaiki (Muslikin 2015). Hal tersebut dapat mengakibatkan berkurangnya luasan lahan yang digunakan untuk kegiatan pertanian secara signifikan dapat menganggu stabilitas kemandirian, ketahanan dan kedaulatan pangan baik lokal maupun nasional.

Selain alih fungsi lahan, hasil produktivitas lahan pertanian juga dipengaruhi oleh perubahan beberapa parameter iklim. Variabilitas iklim di Indonesia erat kaitannya dengan El Nino yang terjadi di Samudera Pasifik dan Samudera Hindia (Naylor et al. 2002 dan Jourdain et al. 2013). Kondisi kekeringan yang diakibatkan oleh El Nino menimbulkan dampak yang signifikan terhadap strategi budaya dan produksi pertanian terutama tanaman pangan (Haylock dan McBride, 2001). Menurut penelitian yang dilakukan oleh Handoko et al. (2008) disebutkan bahwa

${ }^{*}$ Fak. Pertanian UNS Surakarta

JI. Ir. Sutarmi 36A Surakarta variabilitas dan perubahan iklim dengan segala dampaknya berpotensi dapat menyebabkan kehilangan produksi tanaman pangan seperti $20,6 \%$ pada padi, $13,6 \%$ pada jagung dan $12,4 \%$ pada kedelai. Oleh karena itu, perlu diketahui dampak-dampak yang terjadi akibat alih fungsi tataguna lahan pertanian ke nonpertanian, serta pengaruh alih fungsi lahan dan perubaahan iklim yang terjadi terhadap produktivitas pertanian.

\section{METODE PENELITIAN}

Penelitian yang dilakukan merupakan penelitian deskriptif kuantitatif. Informasi alih fungsi lahan di wilayah Kecamatan Jumantono berasal dari BPS Karanganyar dan Citra Google Earth, data curah hujan, suhu udara dan kelembaban udara berasal dari Laboratorium Jumantono FP UNS, serta data produktivitas lahan berasal dari arsip desa Desa Sambirejo, Desa Sukosari, Desa Tugu, Desa Ngunut dan Desa Sedayu. Karakter fisik wilayah Kecamatan Jumantono dibuat dalam bentuk peta menggunakan program software ArcView GIS. Penelitian ini dilakukan pada bulan Maret - Desember 2016

Rancangan yang digunakan adalah rancangan penelitian deskriptif kuantitatif dan analisis statistik. Variabelnya dibagi menjadi: variabel bebas yang meliputi fungsi lahan (lahan sawah, pemukiman, tegalan, padang gembala, tambak, hutan, perkebunan, dan lahan jenis lain-lain) serta variabel terikat yang meliputi perubahan iklim (perubahan curah hujan, suhu udara dan kelembaban udara) dan produktivitas lahan. Data antar variabel diolah agar didapatkan hasil kecenderungan atau trend yang terjadi pada masingmasing variabel. Analisis statistik yang dilakukan adalah analisis statistik korelasi yang bertujuan untuk melihat korelasi-korelasi yang terjadi antara variabel bebas dengan variabel terikat. 


\section{HASIL DAN PEMBAHASAN}

\section{Kecamatan Jumantono}

Kecamatan Jumantono merupakan salah satu dari 17 kecamatan yang ada di Kabupaten Karanganyar. Kecamatan Jumantono terletak di $11 \mathrm{~km}$ arah tenggara dari ibukota Kabupaten Karanganyar. Luas wilayah Kecamatan Jumantono adalah $53,55 \mathrm{~km}^{2}$ dengan ketinggian rata-rata wilayahnya $293 \mathrm{~m}$ di atas permukaan laut (Kecamatan Jumantono Dalam Angka 2014). Peta Administrasi Kecamatan Jumantono terlihat pada Gambar 1. Sedangakan peta lokasi daerah penelitian terlihat pada Gambar 2.

Wilayah penelitian memiliki luas 2356,2 Ha. Desa Sukosari memiliki luas wilayah sebesar 306,4 Ha dan menjadi desa dengan luasan terkecil dalam wilayah penelitian. Desa Tugu memiliki luas 565,2 Ha. Desa Sedayu memiliki luas $654,5 \mathrm{Ha}$ dan menjadi desa dengan luas wilayah paling besar dalam wilayah penelitian. Desa Sambirejo memiliki luas 346,8 Ha. Serta Desa Ngunut memiliki luas 483,3 Ha. Jumlah penduduk daerah penelitian ditunjukkan pada Tabel 1.

Tabel 1 Jumlah penduduk tahun 2003, 2008, 2011, dan 2013

\begin{tabular}{clcccc}
\hline \multirow{2}{*}{ No } & \multirow{2}{*}{ Desa } & \multicolumn{4}{c}{ Jumlah penduduk tahun- (jiwa) } \\
\cline { 3 - 6 } & & 2003 & 2008 & 2011 & 2013 \\
\hline 1 & Sukosari & 2.679 & 2.865 & 2.857 & 2.904 \\
2 & Tugu & 5.013 & 5.221 & 4.162 & 4.262 \\
3 & Sedayu & 5.293 & 5.641 & 3.913 & 4.018 \\
4 & Sambirejo & 3.226 & 3.413 & 3.262 & 3.290 \\
5 & Ngunut & 3.561 & 3.728 & 3.363 & 3.444 \\
\hline & Jumlah & 19.772 & 20.868 & 17.557 & 17.918 \\
\hline
\end{tabular}

Sumber: BPS, Kecamatan Jumantono Dalam Angka Tahun 2003, 2009, 2012 dan 2014

Jumlah penduduk pada lokasi penelitian cenderung lebih fluktuatif. Pada tahun 2003, Desa Sedayu dengan jumlah penduduk 5.293 jiwa. Desa Sukosari merupakan desa dengan jumlah penduduk paling sedikit yaitu 2.679 jiwa. Pada tahun 2008, jumlah penduduk paling banyak terdapat di Desa Sedayu mencapai 5.641 jiwa. Jumlah penduduk paling sedikit terdapat di Desa Sukosari yaitu 2.865 jiwa. Tahun 2011 terjadi penurunan jumlah penduduk pada lokasi penelitian. Jumlah penduduk paling banyak terdapat di Desa Tugu yaitu 4.162 jiwa. Pada tahun 2013 terjadi peningkatan jumlah penduduk pada lokasi penelitian dimana Desa Tugu merupakan desa dengan penduduk paling banyak yaitu 4.262 jiwa.

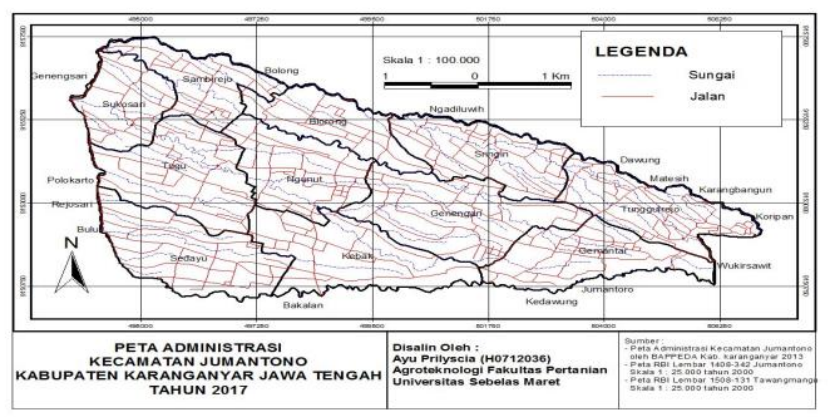

Gambar 1 Peta administrasi kecamatan Jumantono

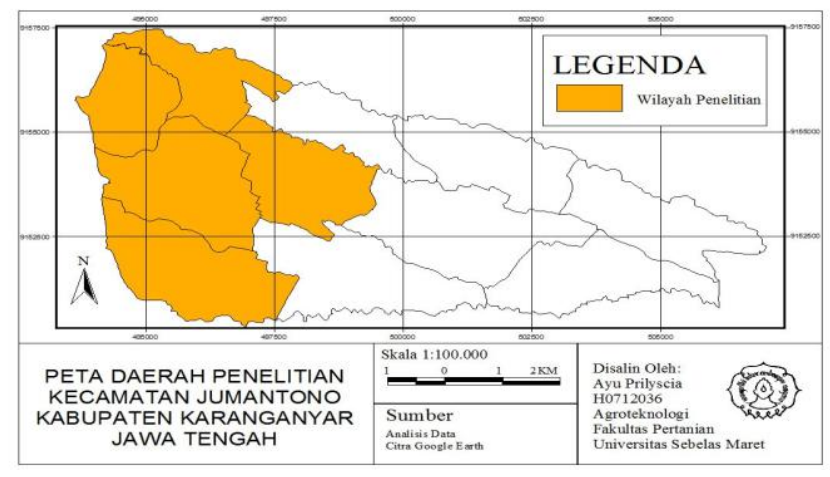

Gambar 2 Peta lokasi daerah penelitian

\section{Alih fungsi lahan}

Perubahan tata guna lahan merupakan bertambah atau berkurang suatu penggunaan lahan dari satu penggunaan lahan ke penggunaan lahan lainnya dari waktu ke waktu, atau dapat juga dikatakan sebagai perubahan fungsi pada suatu lahan dalam kurun waktu yang berbeda (Martin 1993 dalam Wahyunto et al., 2001). Berdasarkan Tabel 2 dapat diketahui bahwa perubahan luas terjadi pada periode tahun 2006-2007. Luas lahan sawah adalah 776,4 Ha. Mengalami penurunan 1,2 Ha pada tahun 2006 sampai 2007 menjadi 775,2 $\mathrm{Ha}$ dan luas lahan ini cenderung tetap sampai tahun 2014. Luas lahan kebun tegalan yaitu $806,9 \mathrm{Ha}$. Lahan kebun tegalan mengalami penurunan luas pada tahun 2006 sampai 2007 sebesar 9,0 Ha menjadi 797,9 $\mathrm{Ha}$. Luas lahan pemukiman yaitu 678,6 Ha. Terjadi peningkatan luasan lahan sebesar 10,2 Ha dari tahun 2006 sampai tahun 2007 menjadi 688,8 Ha. Pada lahan padang gembala, luas lahan cenderung tidak berubah yaitu 5,2 Ha sejak tahun 2002 sampai 2014. Lahan lain-lain pun cenderung tidak mengalami perubahan luas dari tahun 2002 sampai 2014 yaitu 89,1 $\mathrm{Ha}$.

Menurut hasil perhitungan dari data Google Earth yang terdapat pada Tabel 3 terjadi peningkatan luas lahan bangunan dan pekarangan sebesar 7,87 Ha pada tahun 2011 menjadi 695,05 Ha. Pada tahun 2014 luas penggunaan lahan bangunan dan pekarangan mengalami peningkatan 4,50 Ha menjadi 699,55 Ha. Luas penggunaan lahan tegalan pada tahun 2004 sebesar 815,89 Ha. Terjadi penurunan luas penggunaan lahan tegalan sebesar 4,52 Ha pada tahun 2011 menjadi 811,37 Ha. Menurut hasil perhitungan dari data Google Earth, luas tegalan mengalami sedikit pengurangan pada tahun 2014 yaitu $3,80 \mathrm{Ha}$ menjadi $807,57 \mathrm{Ha}$. Luas penggunaan lahan sawah pada tahun 2004 sebesar 794,65 Ha. Luas penggunaan lahan tersebut mengalami pengurangan sebesar 3,66 $\mathrm{Ha}$ menjadi 790,99 Ha. Pada tahun 2014 penggunaan lahan sawah kembali mengalami pengurangan luas lahan sebesar 0,98 Ha menjadi 790,01 Ha. Luas lahan lain-lain pada tahun 2004 adalah 7,46 Ha. Pada tahun 2011 luas penggunaan lahan lain-lain adalah 7,80 $\mathrm{Ha}$. Luasan tersebut meningkat kembali pada tahun 2014 sebesar 0,28 Ha menjadi 8,08 $\mathrm{Ha}$.

Verburg et al. (2001) dalam Huang et al (2009) menyebutkan bahwa perubahan lahan secara langsung dipengaruhi oleh dinamika perubahan jumlah 
penduduk. Hal tersebut berpengaruh terhadap kegiatan-kegiatan di sektor industri dan perkembangan lingkungan perkotaan baru. Sumaryanto et al. (1995) dalam Irawan (2012) menyatakan bahwa sektor perekonomian masih mendominasi alasan terjadinya konversi lahan baik untuk konversi ke penggunaan non pertanian maupun pertanian. Peta penggunaan lahan Google Earth tahun 2004, 2011 serta tahun 2014 dapat dilihat pada Gambar 3, Gambar 4, dan Gambar 5.

Tabel 2 Tata guna lahan periode tahun 2002-2014

\begin{tabular}{lcccccc}
\hline \multirow{2}{*}{ Tahun } & \multicolumn{5}{c}{ Luas Penggunaan Lahan $(\mathrm{Ha})$} & \multirow{2}{*}{ Jumlah } \\
\cline { 2 - 5 } & Sawah & Kebun Tegalan & Pemukiman & Padang Gembala & Lain-lain & \\
\hline 2002 & 776,4 & 806,9 & 678,6 & 5,2 & 89,1 & 2356,2 \\
2003 & 776,4 & 806,9 & 678,6 & 5,2 & 89,1 & 2356,2 \\
2004 & 776,4 & 806,9 & 678,6 & 5,2 & 89,1 & 2356,2 \\
2005 & 776,4 & 806,9 & 678,6 & 5,2 & 89,1 & 2356,2 \\
2006 & 776,4 & 806,9 & 678,6 & 5,2 & 89,1 & 2356,2 \\
2007 & 775,2 & 797,9 & 688,8 & 5,2 & 89,1 & 2356,2 \\
2008 & 775,2 & 797,9 & 688,8 & 5,2 & 89,1 & 2356,2 \\
2009 & 775,2 & 797,9 & 688,8 & 5,2 & 89,1 & 2356,2 \\
2010 & 775,2 & 797,9 & 688,8 & 5,2 & 89,1 & 2356,2 \\
2011 & 775,2 & 797,9 & 688,8 & 5,2 & 89,1 & 2356,2 \\
2012 & 775,2 & 797,9 & 688,8 & 5,2 & 89,1 & 2356,2 \\
2013 & 775,2 & 797,9 & 688,8 & 5,2 & 89,1 & 2356,2 \\
2014 & 775,2 & 797,9 & 688,8 & 5,2 & 89,1 & 2356,2 \\
\hline
\end{tabular}

Sumber : BPS, Kecamatan Jumantono Dalam Angka

Tabel 3 Perubahan luas lahan menurut data google earth tahun 2004, 2011 dan 2014

\begin{tabular}{llrrr}
\hline \multirow{2}{*}{ No } & \multirow{2}{*}{ Penggunaan Lahan } & \multicolumn{3}{c}{ Luas Lahan Tahun (Ha) } \\
\cline { 3 - 5 } & Bangunan dan Pekarangan & 2004 & 2011 & 2014 \\
\hline 1 & Tegalan & 687,21 & 695,05 & 699,55 \\
2 & Sawah & 715,89 & 811,37 & 807,57 \\
3 & Lain-lain & 794,65 & 790,99 & 790,01 \\
4 & Jumlah & 7,46 & 7,80 & 8,08 \\
\hline
\end{tabular}

Sumber: Hasil Analisis Google Earth

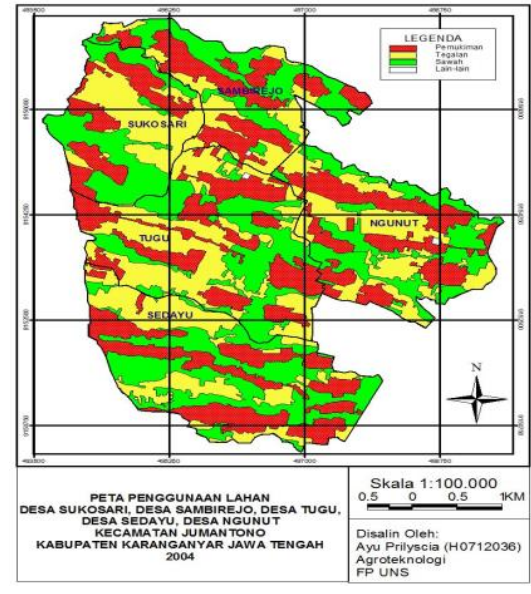

(a)

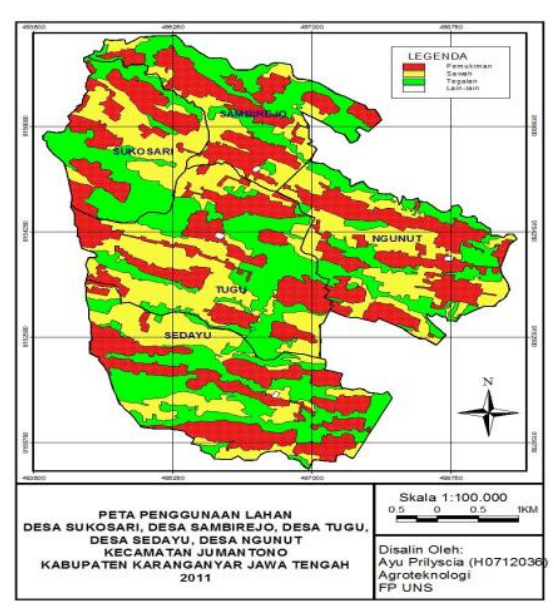

(b)

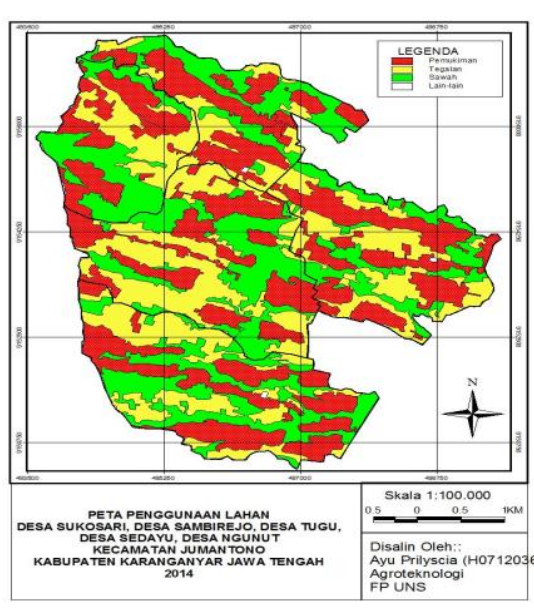

(c)

Gambar 3 Peta penggunaan lahan menurut citra google earth (a) 2004, (b) 2011, (c) 2014

\section{Iklim}

Perubahan iklim disebabkan oleh pemanasan global yang diakibatkan oleh adanya efek Gas Rumah Kaca (GRK) yang menyelubungi atmosfer yang telah mengubah cara atmosfer menyerap energi. (Ginoga et al., 2007). Menurut IPCC (2007) pada tahun 2004, emisi gas rumah kaca mencapai 49 giga ton (milyar ton) $\mathrm{CO}_{2}$. Peningkatan emisi gas terebut diprediksi akan terus meningkat hingga pada periode tahun 20002030 dimana peningkatan emisi gas yang terjadi sebesar $25-90 \%$.
Hasil analisis data menunjukkan bahwa pada tahun 2002-2014 terjadi kecenderungan peningkatan curah hujan dan suhu udara. Tabel 4 menunjukkan bahwa rata-rata curah hujan tertinggi di Jumantono periode tahun 2002-2014 terjadi pada tahun 2010 yaitu 315,00 $\mathrm{mm} /$ tahun. Menurut Visa (2006) dalam penelitian Putri (2013) keragaman curah hujan yang sangat tinggi ditentukan menurut waktu maupun menurut tempat. Peningkatan curah hujan yang terjadi diakibatkan oleh kenaikan aktivitas konveksi (naiknya massa udara karena pemanasan global) pada daerah tertentu. 
Rata-rata suhu udara tertinggi terjadi tahun 2007, 2013 dan 2014 yaitu $27,6^{\circ} \mathrm{C}$. Menurut IPCC (2007) dalam laporannya tahun 2001, disimpulkan bahwa sejak tahun 1861, terjadi peningkatan temperatur udara sebesar $0,6^{\circ}$ Celcius ( $1^{\circ}$ Farenheit). Peningkatan suhu tersebut disebabkan oleh peningkatan aktivitas manusia yang menambah gas-gas rumah kaca ke atmosfer. IPCC juga memprediksi bahwa akan terjadi peningkatan temperatur rata-rata global sebesar 1,1 hingga $6,4^{\circ} \mathrm{C}\left(2,0\right.$ hingga $\left.11,5^{\circ} \mathrm{F}\right)$. Kondisi tersebut akan menyebabkan iklim terus menghangat selama periode tertentu akibat emisi serta karbon dioksida yang telah dilepaskan pada periode sebelumnya akan tetap berada di atmosfer selama seratus tahun atau lebih sebelum alam mampu menyerapnya kembali (Stocker et al. 2007).
Tahun 2002-2014 terjadi trend penurunan kelembaban udara. Kelembaban udara tertinggi di Kecamatan Jumantono terjadi pada tahun 2010 yaitu $82,1 \%$. Kelembaban udara yaitu suatu kandungan uap air yang terdapat di dalam udara (Putri, 2013). Besarnya kelembaban udara sangat dipengaruhi oleh besarnya suhu udara. Penurunan suhu udara yang terjadi dapat menyebabkan defisit uap air menurun, sehingga kapasitas udara dalam upaya menampung uap air juga menurun yang kemudian hal tersebut akan menyebabkan terjadinya peningkatan kelembaban udara (Prasetyo, 2013). Perubahan iklim rata-rata Kecamatan Jumantono tahun 2002-2014 disajikan pada Tabel 4 berikut.

Tabel 4 Perubahan beberapa parameter iklim periode tahun 2002-2014

\begin{tabular}{lccc}
\hline \multirow{2}{*}{ Tahun } & \multicolumn{3}{c}{ Rata-rata } \\
\cline { 2 - 4 } & Curah Hujan (mm/tahun) & Suhu Udara $\left({ }^{\circ} \mathbf{C}\right)$ & Kelembaban Udara $(\%)$ \\
\hline 2002 & 140,42 & 27,5 & 79,34 \\
2003 & 137,58 & 27,0 & 76,02 \\
2004 & 136,42 & 26,9 & 79,46 \\
2005 & 180,25 & 26,7 & 79,45 \\
2006 & 139,75 & 27,1 & 74,87 \\
2007 & 235,50 & 27,6 & 74,64 \\
2008 & 182,17 & 27,3 & 74,55 \\
2009 & 182,67 & 27,4 & 75,84 \\
2010 & 315,00 & 27,4 & 82,09 \\
2011 & 235,17 & 27,2 & 78,82 \\
2012 & 178,92 & 27,3 & 76,21 \\
2013 & 215,83 & 27,6 & 77,02 \\
2014 & 167,92 & 27,6 & 75,90 \\
\hline
\end{tabular}

Sumber: Data Klimatologi Stasiun Puslitbang FP UNS

\section{Produktivitas lahan}

Perubahan tata guna lahan juga secara tidak langsung akan berpengaruh terhadap produktivitas lahan pertanian melalui perubahan iklim seperti perubahan pola curah hujan. Perubahan pola hujan yang terjadi dapat menyebabkan terjadinya ancaman kekeringan ataupun banjir yang dapat mempengaruhi produktivitas lahan. Dalam hal ini, menurut Las et al (2008) pertanian, terutama pada sektor tanaman pangan paling rentan terhadap perubahan pola curah hujan karena tanaman pangan kebanyakan merupakan tanaman semusim yang relatif lebih sensitif terhadap cekaman (kelebihan serta kekurangan) air.

Tabel 5 menunjukkan bahwa produksi padi tertinggi terjadi pada tahun 2005 yaitu 1.028 ton. Produksi padi terendah terjadi pada tahun 2014 yaitu 754 ton. Produksi jagung terendah terjadi pada tahun 2002 yaitu
288 ton. Produksi jagung tertinggi terjadi pada tahun 2011 sebesar 421 ton. Produksi singkong terendah terjadi tahun 2002 sebesar 205 ton. Produksi singkong tertinggi terjadi tahun 2013 sebesar 1.162 ton. Produksi ubi jalar tertinggi terjadi tahun 2012 sebesar 125 ton sedangkan produksi terendahnya terjadi tahun 2002 sebesar 26,5 ton. Produksi kacang tanah tertinggi terjadi tahun 2004 yaitu 53 ton dan produksi terendah terjadi tahun 2012 yaitu 17 ton. Produksi kedelai tertinggi terjadi pada tahun 2013 yaitu 89 ton dimana produksi kedelai pada tahun-tahun sebelumnya tidak terjadi perubahan produksi yang signifikan. Durian mulai diproduksi pada tahun 2011 yaitu sebesar 0,2 ton. Produksi durian mengalami peningkatan untuk tahun-tahun berikutnya. Pada tahun 2014 produksi durian mencapai 1,5 ton.

Tabel 5 Jumlah hasil panen periode tahun 2002-2014

\begin{tabular}{lrrrrrrrr}
\hline \multirow{2}{*}{ Tahun } & \multicolumn{7}{c}{ Hasil Panen (ton) } & $\begin{array}{r}\text { Jumlah } \\
\text { (ton) }\end{array}$ \\
\cline { 2 - 7 } & \multicolumn{1}{c}{ Padi } & Jagung & Singkong & Ubi Jalar & Kacang Tanah & Kedelai & Durian & $27,375,1$ \\
2002 & 775 & 288 & 205 & 26,5 & 27 & 53,6 & 0 & $1.37,4$ \\
2003 & 827 & 386 & 374 & 27,0 & 22 & 56,4 & 0 & $1.692,4$ \\
2004 & 912 & 382 & 690 & 85,0 & 53 & 64,0 & 0 & 2.186 \\
2005 & 1028 & 405 & 632 & 63,0 & 40 & 72,0 & 0 & 2.240 \\
2006 & 924 & 369 & 768 & 72,0 & 39 & 62,0 & 0 & 2.234 \\
2007 & 949 & 313 & 795 & 124,0 & 34 & 64,5 & 0 & 2.279 \\
2008 & 845 & 354 & 933 & 104 & 34 & 62 & 0 & 2.332 \\
\hline
\end{tabular}




\begin{tabular}{lrrrrrrrr}
\hline \multirow{2}{*}{ Tahun } & \multicolumn{7}{c}{ Hasil Panen (ton) } & $\begin{array}{r}\text { Jumlah } \\
\text { (ton) }\end{array}$ \\
\cline { 2 - 7 } & \multicolumn{1}{c}{ Padi } & Jagung & Singkong & Ubi Jalar & Kacang Tanah & Kedelai & Durian & 2.492 \\
2009 & 905 & 365 & 1.050 & 95 & 40 & 37 & 0 & 2.490 \\
2010 & 948 & 322 & 1.029 & 98 & 29 & 64 & 0 & $2.520,2$ \\
2011 & 898 & 421 & 978 & 123 & 38 & 62 & 0,2 & $2.432,3$ \\
2012 & 790 & 413 & 1.038 & 125 & 17 & 49 & 0,3 & $2.606,8$ \\
2013 & 841 & 380 & 1.162 & 108 & 26 & 89 & 0,8 & $2.444,5$ \\
2014 & 754 & 413 & 1.056 & 111 & 31 & 78 & 1,5 & \\
\hline
\end{tabular}

Sumber : Arsip Desa Tahun 2002-2014

\section{Hasil analisis korelasi}

Hasil korelasi alih fungsi lahan (menurut data BPS dan Google Earth) terhadap perubahan produktivitas lahan dapat dilihat pada Tabel 6 dan Tabel 7. Tabel 6 menunjukkan bahwa penurunan luas lahan sawah akan berkorelasi terhadap peningkatan produksi singkong dan ubi jalar. Penurunan lahan kebun tegalan dan peningkatan lahan pemukiman juga berkorelasi terhadap peningkatan produksi singkong dan ubi jalar. Penggunaan lahan padang gembala dan lahan lain-lain tidak menghasilkan suatu angka korelasi dikarenakan luas penggunaan lahan padang gembala dan lahan lain-lain tetap sejak tahun 2002 sampai 2014. Tabel 7 menunjukkan bahwa perubahan penggunaan lahan tegalan berkorelasi terhadap produksi jagung. Perubahan penggunaan lahan sawah berkorelasi terhadap produksi singkong dan kacang tanah. Hasil korelasi tersebut menjelaskan bahwa perubahan luas lahan yang terjadi akan berpengaruh terhadap hasil produksi pertanian. Hal tersebut dikarenakan semakin meningkatnya jumlah area terbangun sehingga menjadikan semakin berkurangnya jumlah lahan bebas yang digunakan untuk produksi pertanian.

Menurut penelitian yang dilakukan oleh Handoko (2008) menyebutkan bahwa menjelang tahun 2050, tanpa upaya adaptasi perubahan iklim secara nasional, produksi padi diperkirakan akan menurun $20,3-27,1 \%$; produksi jagung 13,6\%; produksi kedelai $12,4 \%$; dan produksi tebu 7,6\% dibandingkan dengan tahun 2006. Potensi dan peluang penurunan produksi lahan tersebut terkait dengan berkurangnya lahan sawah di Jawa seluas 113.003-146.437 Ha, di Sumatera Utara 1.314-1.345 Ha, dan di Sulawesi 13.672-17.069 Ha. Mengacu pada penelitian yang dilakukan Handoko, ada indikasi bahwa produksi tanaman pangan bergantung pada luasan lahan sawah. Artinya bahwa semakin luas lahan sawah maka produksi tanaman pangan akan semakin meningkat (hal tersebut di luar adanya upaya adaptasi perubahan iklim).

Tabel 6 Korelasi penggunaan lahan (BPS) terhadap perubahan produktivitas lahan tahun 2002-2014

\begin{tabular}{|c|c|c|c|c|c|c|c|c|}
\hline Variabel & & Padi & Jagung & Singkong & $\begin{array}{l}\text { Ubi } \\
\text { Jalar }\end{array}$ & $\begin{array}{c}\text { Kacang } \\
\text { Tanah }\end{array}$ & Kedelai & Durian \\
\hline \multirow[t]{2}{*}{ Sawah } & Pearson Correlation & 172 &,- 081 &,- 832 &,- 847 & ,276 &,- 062 &,- 395 \\
\hline & Sig. (1-tailed) & 287 & ,396 &, 000 &, 000 &, 181 & 420 & 091 \\
\hline \multirow[t]{2}{*}{ Kebun Tegalan } & Pearson Correlation & 172 &,- 081 &,- 832 &,- 847 & ,276 &,- 062 &,- 395 \\
\hline & Sig. (1-tailed) & ,287 & ,396 &, 000 &, 000 & 181 & ,420 & 091 \\
\hline \multirow[t]{2}{*}{ Pemukiman } & Pearson Correlation &,- 172 & 081 & 832 & 847 &,- 276 & 062 & ,395 \\
\hline & Sig. (1-tailed) & 287 & 396 &, 000 &, 000 &, 181 &, 420 &, 091 \\
\hline \multirow{2}{*}{$\begin{array}{l}\text { Padang } \\
\text { Gembala }\end{array}$} & Pearson Correlation & $\mathrm{b}$ & $\mathrm{b}$ & $B$ & $\mathrm{~b}$ & $\mathrm{~b}$ & $\mathrm{~B}$ & $\mathrm{~B}$ \\
\hline & Sig. (1-tailed) & - & - & - & - & - & - & - \\
\hline \multirow[t]{2}{*}{ Lain-lain } & Pearson Correlation & $\mathrm{b}$ & $\mathrm{b}$ & $B$ & $\bar{b}$ & $\mathrm{~b}$ & $\mathrm{~B}$ & $\mathrm{~B}$ \\
\hline & Sig. (1-tailed) & - & - & - & - & - & - & \\
\hline
\end{tabular}

Keterangan: b tidak dapat dikorelasikan karena variabel bersifat konstan , ${ }^{*}$ korelasi signifikan pada taraf 0,05 , ${ }^{* \star}$ korelasi signifikan pada taraf $0.01,-/+$ menunjukkan hubungan korelasi variabel bersifat negatif / positif

Tabel 7 Korelasi penggunaan lahan (Google Earth) terhadap perubahan produktivitas lahan tahun 2002-2014

\begin{tabular}{|c|c|c|c|c|c|c|c|c|}
\hline Variabel & & Padi & Jagung & Singkong & $\begin{array}{l}\text { Ubi } \\
\text { Jalar }\end{array}$ & $\begin{array}{l}\text { Kacang } \\
\text { Tanah }\end{array}$ & Kedelai & Durian \\
\hline \multirow{2}{*}{$\begin{array}{l}\text { Bangunan dan } \\
\text { Pekarangan }\end{array}$} & Pearson Correlation &,- 578 & 979 & ,982 & ,947 &,- 954 &, 408 &, 612 \\
\hline & Sig. (1-tailed) & ,304 & 066 &, 061 &, 104 & 097 &, 366 & $\overline{290}$ \\
\hline \multirow[t]{2}{*}{ Tegalan } & Pearson Correlation & ,523 &,- 990 &,- 967 &,- 966 & 932 &,- 348 &,- 559 \\
\hline & Sig. (1-tailed) & ,325 &, 045 &, 082 & ,083 &, 118 & ,387 & ,311 \\
\hline \multirow[t]{2}{*}{ Sawah } & Pearson Correlation & ,721 &,- 922 &,- 000 &,- 870 & ,993 &,- 573 &,- 750 \\
\hline & Sig. (1-tailed) & ,244 &, 126 & $001^{\prime \prime}$ & 164 & 037 &, 306 & 230 \\
\hline \multirow[t]{2}{*}{ Lain-lain } & Pearson Correlation & ,878 &, 788 & 965 & ,710 &,- 989 & ,768 & ,898 \\
\hline & Sig. (1-tailed) &, 159 &, 211 &, 084 & ,249 &, 048 &, 221 &, 145 \\
\hline
\end{tabular}

Keterangan: *korelasi signifikan pada taraf 0,05

** korelasi signifikan pada taraf 0.01

$-/$ + menunjukkan hubugan korelasi variabel bersifat negatif / positif 
Hasil analisis korelasi antara perubahan iklim terhadap perubahan produktivitas lahan dapat dilihat pada Tabel 9 yang menunjukkan bahwa perubahan yang terjadi pada intensitas curah hujan berkorelasi terhadap produksi singkong dan ubi jalar. Peningkatan suhu udara yang terjadi berkorelasi terhadap produksi padi dan durian. Berdasarkan hal tersebut, dapat ditarik kesimpulan bahwa perubahan beberapa parameter iklim yang terjadi berpengaruh terhadap perubahan produktivitas lahan. Hal tersebut dikarenakan perubahan pola hujan yang terjadi dapat menyebabkan terjadinya ancaman kekeringan ataupun banjir yang dapat mempengaruhi produktivitas lahan pertanian terutama pada sektor tanaman pangan. Kejadian iklim yang ekstrem dapat berakibat kepada (a) kegagalan panen, penurunan IP yang berujung pada penurunan prduktivitas dan produksi; (b) kerusakan sumberdaya lahan pertanian; (c) peningkatan frekuensi, luas, dan bobot/intensitas kekeringan; (d) peningkatan kelembaban; dan (e) peningkatan intensitas gangguan organisme pengganggu tanaman.
Menurut kajian dari FAO (2005), variabilitas dan perubahan iklim (terutama curah hujan) yang terjadi akan berpengaruh terhadap $11 \%$ lahan pertanian di negara-negara berkembang. Sementara itu, menurut Fischer et al. (2002), variabilitas iklim yang terjadi akan berpengaruh terhadap penurunan produksi tanaman pangan (serealia) di kawasan Asia Tenggara. Untuk selanjutnya, munculnya kejadian El Nino akan berimplikasi terhadap waktu musim tanam. Hal tersebut dijelaskan oleh Las (2000) bahwa tahun 1997/98 akibat fenomena El Nino, waktu tanam pada tahun 1997/98 telah bergeser hingga 2-3 bulan (6-9 dasarian) sehingga waktu tanam pada musim berikutnya juga mengalami perubahan. Fenomena tersebut berpengaruh terhadap penurunan produksi padi sebesar 6,5\%. Menurut Cline (2007), pada tahun 2080 mendatang penurunan komoditas pangan di Indonesia akibat pengaruh pemanasan global berkisar antara 15$25 \%$. Apabila pengayaan $\mathrm{CO}_{2}$ di atmosfer ikut diperhitungkan maka penurunan produktivitas berkisar antara $15-25 \%$ dari produktivitas saat ini.

Tabel 8 Korelasi perubahan beberapa parameter iklim terhadap perubahan produktivitas lahan tahun $2002-2014$

\begin{tabular}{|c|c|c|c|c|c|c|c|c|}
\hline Variabel & & Padi & Jagung & Singkong & $\begin{array}{c}\text { Ubi } \\
\text { Jalar }\end{array}$ & $\begin{array}{c}\text { Kacang } \\
\text { Tanah }\end{array}$ & Kedelai & Durian \\
\hline \multirow{2}{*}{ Curah Hujan } & Pearson Correlation & ,364 &,- 196 &, 543 &, 547 &,- 141 & ,195 &,- 007 \\
\hline & Sig. (1-tailed) &, 111 & ,261 & $028^{*}$ &, 026 & ,323 & ,261 & ,491 \\
\hline \multirow{2}{*}{ Suhu Udara } & Pearson Correlation &,- 506 &,- 410 & ,387 & ,413 &,- 433 &, 107 & ,477 \\
\hline & Sig. (1-tailed) & 039 &, 082 &, 096 & ,081 & 070 & ,364 &, $050^{\prime}$ \\
\hline \multirow{2}{*}{$\begin{array}{l}\text { Kelembaban } \\
\text { Udara }\end{array}$} & Pearson Correlation & ,289 &,- 123 &,- 154 &,- 205 &, 154 &, 110 &,- 174 \\
\hline & Sig. (1-tailed) & ,169 & ,345 & ,308 & ,250 & ,307 &, 360 & ,285 \\
\hline
\end{tabular}

Keterangan:

*korelasi signifikan pada taraf 0,05

${ }^{* *}$ korelasi signifikan pada taraf 0.01

$-/$ + menunjukkan hubugan korelasi variabel bersifat negatif / positif

\section{KESIMPULAN DAN SARAN}

\section{Kesimpulan}

Berdasarkan hasil penelitian dapat ditarik kesimpulan sebagai berikut.

1. Terjadi perubahan luas penggunaan lahan menurut BPS pada tahun 2006-2007 dan terjdi perubahan luas penggunaan lahan menurut Citra Google Earth tiap tahunnya pada tahun 2004, 2011, dan 2014.

2. Terjadi perubahan iklim di wilayah penelitian. Terjadi trend peningkatan pada intensitas curah hujan serta peningkatan suhu udara. Tetapi pada kelembaban udara, trend yang terjadi adalah trend penurunan.

3. Terdapat hubungan korelasi antara perubahan luas penggunaan lahan dengan perubahan produktivitas pertanian.

4. Terdapat hubungan korelasi antara perubahan iklim dengan perubahan produktitas pertanian.

\section{DAFTAR PUSTAKA}

Cline WR. 2007. Global warming and agriculture: impact estimate by country. Center for Global Development and Peterson Institute for International Economics. Washington: United States.

FAO. 2005. Impact of climate change and diseases on food security and proverty reduction. Spesial Event
Background Document for The 31st Session of Committee on World Food Security. Rome 23-26 May 2005.

Fischer G, Shah M, Velthuizen HV. 2002. Climate change and agricultural vulnerability. IIASA. Luxemburg: Austria.

Ginoga KL, AN Ginting, A Wibowo. 2007. Isu pemanasan global, UNFCC kyoto protocol dan peluang aplikasi $\mathrm{a} / \mathrm{r} \mathrm{cdm}$ di indonesia. Badan Litbang Kehutanan: Jakarta.

Handoko I, Sugiarto Y, Syaukat Y. 2008. Keterkaitan perubahan iklim dan produksi pangan strategis. Telaah Kebijakan oleh Kemitraan/Partnership Indonesia. SEAMEO BIOTROP. Bogor.

Handoko TH. 2008. Manajemen personalia. BPFE Yogyakarta: Yogyakarta

Haylock M, McBride J. 2001. Spatial coherence and predictability of indonesian wet season rainfall. $J$ Climate. 14: 3882-3887.

Huang BO, L Zhang, B Wu. 2009. Spatio-temporal analysis of rural-urban land conversion. International Journal of Geographical Information Science. 23(10): 1-27. 
IPCC. 2007. Task group data and scenario support for impacts and climate analysis (TGCIA). General Guidelines on The Use of Scenario Data for Climate Impact and Adaptation Assessement. Version 2. Pp. 66.

IPCC. 2007. Contribution of working groups i, ii, and iii to the fourth assessment report of the intergovermmental panel on climate change core writing team. Pachauri, R.K. and Reisinger, A. (Eds). IPCC. Geneva. Switzerland. Pp 104.

Irawan B, Prayitno. 2012. Dampak koversi lahan sawah di jawa terhadap produksi beras dan kebijakan pengedaliannya. Pusat Penelitian dan Pengembangan Sosial Ekonomi Pertanian Bogor.

Jourdain NC, Aleander San Gupta, Andreas S., Taschetto CC, Ummenhofer, Aurel FM, Karumuri A. 2013. The indo-australian monsoon and it's relationship to ENSO and IOD in reanalysis data and the CMIP3/CMIP5 simulations. Journal of Climate Dynamics 41(11): 3073-3102.

Las I. 2000. Peluang kejadian el nino dan la nina tahun 1999-2000. Pusat Penelitian dan Pengembangan Tanaman Pangan. Badan Litbang Pertanian: Bogor.

Las I, Surmaini, A Ruskandar. 2008. Antisipasi perubahan iklim: inovasi teknologi dan arah penelitian padi di indonesia. Prosiding Seminar Nasional Padi 2008. Inovasi Teknologi Padi engantisipasi Perubahan Iklmim Global Mendukung Ketahanan Pangan. BB. Padi.

Muslikin MK. 2015. Kajian alih fungsi lahan sawah menjadi non-sawah dan dampak terhadap produksi padi di kabupaten blora tahun 2000-2010. Skripsi Jurusan Geografi, Fakultas IImu Sosial. Universitas Negeri Semarang: Semarang.

Naylor RL, Falcon W, Wada N, Rochberg D. 2002. Using el nino southern oscillation climate data ti improve food policy in indonesia. Bulletin of Indonesian Economic Studies. 38: 75-91.

Prasetyo AT. 2013. Pengaruh ruang terbuka hijau (rth) terhadap iklim mikro di kota pasuruan. Jurusan geografi. Program Studi Pendidikan Geografi. Fakulltas IImu Sosial. Universitas Negeri Malang: Malang.

Priyono. 2011. Alih fungsi lahan pertanian merupakan suatu kebutuhan atau tantangan. Prosiding Seminar Nasional Budidaya Pertanian, Bengkulu 7 Juli 2011.

Putri, Dian MD. 2013. Analisis suhu udara dan curah hujan untuk deteksi perubahan iklim kabupaten karanganyar tahun 1988-2011. Fakultas Keguruan dan IImu Pendidikan. Universitas Sebelas Maret: Surakarta

Stocker, Thomas F. 2001. The scientific basis. Contribution of working group $i$ to the third assessmenr report of the intergovermmental panel climate on climate change. Intergovermmental Panel on Climate Change.

Wahyunto M, Zainal Abidin, Adi Priyono, Sunaryo. 2001. Studi perubahan lahan di sub DAS citarik, jawa barat dan DAS kaligarang, jawa tengah. Prosiding Seminar Nasiona Multifungsi Lahan Sawah. Hal 39-40. Bogor. ISBN: 979-9474-06-X. 